University of Nebraska - Lincoln

DigitalCommons@University of Nebraska - Lincoln

Investigations of the Ichthyofauna of

Nicaraguan Lakes

Papers in the Biological Sciences

1976

\title{
Cross-fostering and Parent-offspring Responses in Cichlasoma citrinellum (Pisces, Cichlidae)
}

\author{
David L. G. Noakes \\ University of Guelph \\ George W. Barlow \\ University of California - Berkeley
}

Follow this and additional works at: https://digitalcommons.unl.edu/ichthynicar

Part of the Aquaculture and Fisheries Commons

Noakes, David L. G. and Barlow, George W., "Cross-fostering and Parent-offspring Responses in Cichlasoma citrinellum (Pisces, Cichlidae)" (1976). Investigations of the Ichthyofauna of Nicaraguan Lakes. 30.

https://digitalcommons.unl.edu/ichthynicar/30

This Article is brought to you for free and open access by the Papers in the Biological Sciences at DigitalCommons@University of Nebraska - Lincoln. It has been accepted for inclusion in Investigations of the Ichthyofauna of Nicaraguan Lakes by an authorized administrator of DigitalCommons@University of Nebraska Lincoln. 
Z. Tierpsychol., 33, 147-152 (1973)

(C) 1973 Verlag Paul Parey, Berlin und Hamburg

ISSN 0044-3573 / ASTM-Coden: ZETIAG

Department of Zoology, and Museum of Vertebrate Zoology, University of California, Berkeley, California, 94720

\title{
Cross-fostering and Parent-offspring Responses in Cicblasoma citrinellum (Pisces, Cichlidae ${ }^{1}$ )
}

\author{
By \\ David L. G. Noakes and George W. Barlow
}

Received: 28.6 .1972

Harper (1970) has reviewed the literature on experimental analysis of parent-offspring responses among mammals. In contrast, almost nothing is known about comparable relationships in fishes. Since cichlid fish have highly developed social behavior, in many ways comparable to that of some mammals, we think it worthwhile to direct attention to these phenomena, and to point out areas for further investigation.

Parental cichlids, by definition, behave differently toward young which at other times they would ignore or attack. Their parental behavior, especially recognition of young, has been the subject of some studies (NOBLE and CURTIS 1939, Lorenz 1950, Collins and Braddock 1962, Greenberg 1963 a, 1963 b, KüHme 1963, Myrberg 1964). Questions remain, however, about the extent of this recognition and whether it involves learning by the parents (MYrBERG 1966). It is to these questions that this note is directed.

While studying the ontogeny of behavior in Cichlasoma citrinellum (NoAkEs 1971, NoAkes and BARLow 1973) some parents were exchanged between families. Also, an attempt was made to prolong parental behavior in adults; this resulted from a discussion with Donald KRAMER about his research with gouramis (Trichogaster trichopterus). KRAMER and LILEY (1971) reported the results of this research, involving presentations of eggs to induce parental responses in nonparental adults. A similar procedure has induced maternal behavior in rats (ROSENBLATT 1967). We followed this procedure with cichlids, but under different circumstances. While these experiments were not a major part of the study, the results are of sufficient interest to warrant this report.

1) Supported by grant GB 13426 to G.W.B. from the National Science Foundation, U.S. A., and by Teaching Assistantship to D.L.G.N. from Graduate Division, University of California, Berkeley. Use of space and facilities by D. L.G. N. in Zoology Department, University of Edinburgh to complete writing is gratefully acknowledged. Zusammenfassung prepared by F. MORQURDT. 


\section{Background Information}

Cichlasoma citrinellum (Günther) is a cichlid fish native to Nicaragua, Central America. Details of its life history, distribution and xanthic polymorphism are to be published elsewhere (BARLOW in prep.). The reproductive behavior is generally typical of a substrate breeding species (Baerends and BaERends-van Roon 1950). Parents keep the free-swimming young in a compact group close to them, both by retrieving fry in their mouths and by signals such as pelvic fin flickering and lateral jerking of the body. They defend the young vigorously against other fish, both in the laboratory and in nature, and against human observers in the laboratory. During this period the most notable behavior of the young is their contacting of the parents (NOAKES and BARLOw 1968); the young swim to, then eat from, the parents' surface.

Parental care probably continues for about another 3 to 4 weeks. At least no fry judged to be older than this were seen with parents as family groups in the field. And the behavior of fish in the laboratory tends to confirm this (NoAkEs 1971). This suggests 5 to 6 weeks as the duration of the parental cycle.

Parental grey colored (non-xanthic) fish have seven dark vertical bars alternating with very light interspaces along the sides of the body. Nonparental grey colored fish are generally cryptic, with a few dark spots along the sides on a lighter grey background. Xanthic fish usually do not show any obvious color changes.

Nonparental fish chase and eat young, both in the laboratory and in the field. They neither defend the young nor maintain them in a group.

\section{Methods}

Adults were either wild-caught from Lake Masaya, Nicaragua, or first generation bred in our laboratory from such stock. All but one pair had previous breeding and parental experience. Standard lengths (Hubss and Lagler 1958) were 107-181 mm. Both xanthic and grey colored fish were used, but mostly the latter. Aquaria were of two sizes, $2401(90 \mathrm{~cm}$ $\times 60 \mathrm{~cm} \times 45 \mathrm{~cm})$ and $1201(90 \mathrm{~cm} \times 40 \mathrm{~cm} \times 35 \mathrm{~cm})$. Adults were fed a varied diet of live and dried food, twice daily. Young were given nauplii (Artemia salina), microworms ( $A n-$ guillula sp.) or powdered dry food, once daily, in the morning. All fish were in good health throughout the study.

\section{Exchanges of Parents}

Reference to foreign young indicates young of a different pair, not of a different species. Parental fish are those which show typical behavior with their own or other parents' young. This is essentially the same criterion used by others for similar tests ("live or die test", GREENBERG 1963a, MYRBERG 1964).

Parents can be moved, individually or together, to different aquaria, and will continue to behave parentally. They can even be kept isolated in a small (ca. $10 \mathrm{l}$ ) bucket for up to half an hour, and will be actively keeping the young in a group. Threatening the observer commences within minutes of being returned to their aquarium. However, manipulations of fish were kept to a minimum in these tests.

Pairs of fish, each in a 2401 aquarium, were allowed to spawn and raise 100 young. Another group of 100 young from this same spawn was raised in a similar, adjacent aquarium, isolated from all but the sight of their parents and siblings. Parents were exchanged between families when the young were about three weeks of age (since spawning). By then parents and young were interacting normally, including contacting of parents by the young. Parents were exchanged between families around 0900 hours, and were returned to their home aquaria about 1800 hours the same day. Each pair of adults was involved in only one such exchange between families.

\section{Results}

In such exchanges parents accepted foreign young about the same age, or younger than their own, but did not accept foreign young appreciably older than their own (Table 1). 
Table 1: Responses of Parents to Foreign Young

Age in days relative to parents' own young. $+=$ acceptance; $-=$ non-acceptance.

\begin{tabular}{|c|c|c|}
\hline $\begin{array}{l}\text { Relative Age of } \\
\text { Foreign Young }\end{array}$ & $\begin{array}{l}\text { Response of } \\
\text { Parents }\end{array}$ & $\begin{array}{c}\text { Number of } \\
\text { cases }\end{array}$ \\
\hline-35 (approx) & + & $8(*)$ \\
-13 & + & $1(*)$ \\
-10 & + & 1 \\
-2 & + & 1 \\
+2 & + & 1 \\
+10 & - & 1 \\
+13 & - & 1 \\
\hline
\end{tabular}

(*) results from experiment to prolong parental behaviour. (**) all but these two adults had previous reproductive experience.

In addition to parents accenting foreign young and behaving normally toward them, young also accepted the parents. After an initial period of increased swimming activity following exchanges, the young commenced contacting the foreign parents.

Parents which did not accept foreign young almost immediately began chasing and eating them. This continued until all such young were eaten, or until the experiment was terminated. However, on being returned to their home aquaria, all parents accepted their own young again without incident. And in the parallel series of experiments all these parents accepted the groups of their own young which had been raised isolated from any adults.

Adults that had not had young, or had been more than two weeks away from young, did not accept, and usually chased and attempted to catch and eat young fish given to them. At times in the field, juvenile and subadult C. citrinellum are predators on young still with parents (pers. observ.).

\section{Prolonging Parental Behavior}

In Hemichromis bimaculatus, the jewel cichlid, the parental response to chemical cues from the young has been prolonged for up to two weeks beyond normal by presenting younger fry (KüHME 1963). Otherwise there has apparently been no test for this in cichlids.

These observations were on one pair of adult C. citrinellum, but were confirmed in part on other fish at different times. The pair spawned and raised their young in a $240 \mathrm{l}$ aquarium. When the young were six weeks old the parents were removed individually to 1201 aquaria. 50-75 foreign young, about one week old, were given to each parent. With the exception to be noted below, these were accepted without incident. Thereafter, as the young grew, they were replaced at about monthly intervals with successive batches of foreign young one to two weeks of age. All were accepted without incident. Nine months after the pair had spawned they were still parental; the experiment was terminated for other reasons.

Thus parental care can be prolonged for much longer than normal in this species by successive presentations of young fish.

\section{Parental Behavior and Color Pattern}

Some observations on responses to young and color changes in adults are relevant. In two cases, grey colored parents had been alone, each in a 1201 aquarium without young, for seven and nine days, respectively. By then they were showing the typical nonparental color pattern. One of these was the $\delta$ referred to above in the experiment to prolong parental behavior. 
When young one week of age were given to them, these adults first chased, caught and ate some young. After eating about half (ca 25) the young, the adults continued to catch, but stopped eating them, and began to spit them out. At the same time they began to show the barred color pattern typical of parental fish.

At times during the experiment to prolong parental behavior, the adults were barred less intensely than usual. If then provoked to threaten the observer, they quickly developed the more strongly barred pattern. A similar situation was observed with a pair of grey colored fish in Lake Apoyo, Nicaragua. While near the $q$ and the young, the $\delta$ showed the typical barred color pattern. When he moved more than a meter or so a way, but not in pursuit of another fish, his color changed to the typical nonparental color. On returning to the vicinity of the $P$ and young, he quickly regained the barred pattern.

Apparently the tendency to behave parentally can be present without necessarily being expressed by the color pattern. Or perhaps it is more accurate to consider the barred pattern as the 'territorial', rather than the 'parental' color pattern.

\section{Discussion}

Different investigators have shown that parents in several species can discriminate their own young from those of another species (NOBLE and CURTIS 1939, Baerends and Baerends-van Roon 1950, Myrberg 1964). There is also evidence for discrimination between young of the same species but of different families (KüHme 1963). Our observations dealt only with transfers within one species, but the conclusions are of interest as regards parental behavior itself in these fish.

In C. citrinellum, parental fish will apparently accept any young of appropriate age of the same species. Previous breeding and parental experience do not seem to affect this. The critical factor appears to be the relative ages of the young. Parents evidently discriminate young on the basis of their immediately prior experience with young (rather than from previous breeding cycles, for example).

During the parental period adults evidently learn to recognize their young. They may be building up an increasingly complex sensory image of the young. Or they may be responding to successively different cues. Because parents accept fry younger than but not older than their own, they have some 'memory' of their own young and will accept fry which fall within that 'image'. They could not make a simultaneous comparison as could fish used by others in testing parental discrimination.

After about two weeks without young, adults no longer accept any young, apparently having 'lost' this 'memory'. However, the parental state can be induced again by exposing the adults to fry.

MYRBERG (1966) hypothesized that parental cichlids discriminate wrigglers (larvae) primarily on the basis of chemical cues. Then they shift to visual cues, apparently by associative learning, for the discrimination of free-swimming fry. This shift in sensory modality could take place within the scheme we suggest. KüHme (1963) and Myrberg (1966) have shown that chemical cues from eggs and fry of different ages are sufficiently different to allow parental discrimination. Whether or not this is the basis for discrimination by parental C. citrinellum remains to be seen. Transfers of fish between families may be useful for examining the details of this behavior. 
Observations by G.W. B. on another cichlid, Etroplus maculatus, are helpful here. The fry go through three color changes that are much more distinctive than in C. citrinellum. Experienced parents will accept fry of their own species at least two color phases younger. But fry in the next older phase are immediately caught out of the school. These fry, however, are visually foreign but chemically correct. The parent spits the fry out at once, sees the "wrong" fry, engulfs it, gets the "right" taste, spits it out, sometimes repeating this more than 100 times in succession. Suddenly the young is chewed up and swallowed. Most likely it is eventually damaged from this buccal yo-yo, consequently emitting chemical cues that override the specific inhibition.

On the other hand, during the first week only, young of $E$. maculatus and $E$. suratensis have the same color pattern, but the fry of $E$. suratensis are perceptibly the larger. When such an E. suratensis fry is carefully inserted into a family of $E$. maculatus with fry the same age, it remains undetected for a long period. And often when a parent first detects it (raised fins, orienting response) the parent then loses sight of it. Eventually the parent $E$. maculatus catches the little E. suratensis, and eats it forthwith because it is chemically "wrong".

\section{Summary}

Previous studies of parent-young interactions in cichlid fish have established some of the details of such relations, but have raised, or left unanswered many questions. In particular, there are questions as to the recognition of parents and young by each other, and to what extent learning might be involved in such recognition.

Based on observations of exchanges of parents between families of Cicblasoma citrinellum, we suggest that parents learn to recognize young during each parental cycle. They appear to have a moderately short term memory for recognition of young, and accept young corresponding to this memory.

Parental fish accept conspecific fry younger than, or the same age, but not those older than their own. Successive presentations of young fry maintained parental behavior for much longer than normal. Changes in color pattern, and some aspects of parental behavior are described.

\section{Zusammenfassung}

Frühere Arbeiten über Eltern-Kind-Beziehungen an Cichliden haben einige Details einer solchen Beziehung aufgezeigt. Unbeantwortet ist, wie Eltern und Junge sich gegenseitig erkennen und in wieweit ein Lernprozeß an diesem Erkennen beteiligt ist.

Nach Beobachtungen über den Austausch von Elternfischen zwischen Familien von Cichlasoma citrinellum halten wir es für möglich, daß die Eltern ihre Jungen während jedes Brutzyklus neu kennen lernen. Sie scheinen eine Art Kurzzeitgedächtnis für das Erkennen der Jungen zu besitzen und nehmen nur Junge an, die diesem Gedächtnisinhalt entsprechen.

Elternfische nehmen Jungfische der gleichen Art an, wenn sie gleich alt oder jünger als die eigenen sind; ältere Jungfische werden nicht angenommen. Bietet man ständig junge Brut, erhält sich das Brutverhalten sehr viel länger als normal. Anderungen des Farbmusters und einige Aspekte des Pflegeverhaltens sind beschrieben. 


\section{Literature Cited}

Baerends, G. P., and J. M. Baerends-van Roon (1950): An introduction to the study of the ethology of cichlid fishes. Behaviour Suppl. 1, 1-242 - Collins, H. L., and J. C. BRADDOCK (1962): Notes on fostering experiments with the cichlid fishes Tilapia sparmanni and Aequidens portalegrensis. (Abstract) Amer. Zool. 2, 400 - Greenberg, B. (1963a): Parental behavior and imprinting in cichlid fishes. Behaviour 21,127-144 - GREENBERG, B. (1963b): Parental behaviour and recognition of young in Cichlasoma biocellatum. Anim. Behav. 11, 578-582 - Harper, L. V. (1970): Ontogenetic and phylogenetic functions of the parentoffspring relationship in mammals. In: Advances in the Study of Behavior. (Ed. D. S. LEHRman, R. A. Hinde and E. Shaw) 3, 75-117, Academic Press, London - Hubbs, C. L., and K. LAGLER (1958): Fishes of the Great Lakes Region, Cranbrook Institute of Science, Bloomfield, Michigan - Kramer, D., and N. R. Liley (1971): The role of spawning behavior and stimuli from the eggs in the induction of a parental response in the blue gourami, Trichogaster trichopterus (Pisces, Belontiidae). Anim. Behav. 19, 87-92 • Küнme, W. (1963): Chemisch ausgelöste Brutpflege und Schwarmreaktionen bei Hemichromis bimaculatus (Pisces). Z. Tierpsychol. 20, 688-704 - Lorenz, K. (1950): The comparative method in studying innate behaviour patterns. Symp. Soc. Exp. Biol. 4, 221-268 - Myrberg, A. A. (1964): An analysis of the preferential care of eggs and young by adult cichlid fishes. Z. Tierpsychol. 21, 43-98 • Myrberg, A. A. (1966): Parental recognition of young in cichlid fishes. Anim. Behav. 14, 565-571 - NoakfS, D. L. G. (1971): Ontogeny of behavior in a polymorphic cichlid fish, Cichlasoma labiatum (Günther). Doctoral Dissertation, Zoology Department, University of California, Berkeley - Noakes, D. L. G., and G. W. Barlow (1968): Parental behavior in Cichlasoma citrinellum - response of young toward the parents. (Abstract) Amer. Zool. 8, 691 - Noakes, D. L. G., and G. W. Barlow (1973): Ontogeny of parent-contacting behavior in young Cicblasoma labiatum (Pisces, Cichlidae). Behaviour 46, 221-255 - NoвLE, G. K., and B. CuRTIS (1939): The social behavior of the jewel fish Hemichromis bimaculatus Gill. Bull. Amer. Mus. Nat. Hist. B. 76, 1-46 - Rosenblatt, J. S. (1967): Nonhormonal basis of maternal behavior in the rat. Science $156,1512-1514$.

Author's address: D. L. G. Noakes, Zoology Department, University of Guelph, Ontario, Canada, NIG 2WI. 